\title{
Roman Wysocki
}

\author{
Maria Curie-Skłodowska University in Lublin (Poland) \\ Email:wysocki@poczta.umcs.lublin.pl \\ ORCID: https://orcid.org/0000-0002-5664-6041
}

\section{The Stance of the Polish Underground State towards the Polish-Belarusian Talks over the Years 1941-1944}

\author{
Polskie Państwo Podziemne wobec propozycji rozmów polsko-białoruskich \\ w latach 1941-1944 \\ Адносіны Польскай падпольнай дзяржавы да прапановы польска-беларускага пагаднення \\ ў перыяд 1941-1944 г2.
}

\section{Abstract}

This paper gives an account of the talks between the Polish Underground State and members of the Belarusian political communities over the years 1941-1944. Following the attack of the Third Reich on the Soviet Union, the Belarusians found themselves under German occupation, which had an impact both on the Polish Underground State structures and the Belarusian resistance movement. Convinced that the Third Reich was bound to fail, the two organisations should have allied themselves with each other on the premise of common objectives. Were they, however, able to break the deadlock on mutual animosity, distrust, bias, belittling and disparaging? The answer to that question lies in the remaining source material. Upon analysis of archival documents, it is possible to state that the Polish Underground State did not consider the Belarusian resistance movement as a potential partner for cooperation. The Poles maintained a rigid stance on the issue of pre-war borders, which determined the character of the dialogue between the Polish Underground and the Belarusian political environment. They also largely underestimated the resources of the Belarusian resistance, which might have played a key role in reversing the situation in the region. A group of Belarusian activists were persistent in their attempts to contact the Polish Underground State nevertheless. These were Vaclaŭ Ivanoŭski, Jan Stankievič, and Radaslaŭ Astroŭski. However, the talks were low-level and conducted on an irregular basis, and their character was exploratory rather than focusing on particular problems. They were thus futile from the very beginning. Improving Polish-Belarusian relations in the course of the war was an enormous challenge which neither of the parties could cope with, and which ultimately determined the fate of both nations in the post-war period.

Keywords: Polish Underground State, Polish-Belarusian talks, Belarusian national movement, Radaslaŭ Astroŭski, Vaclaŭ Ivanoŭski 


\begin{abstract}
Abstrakt
Tematem artykułu są rozmowy prowadzone przez Polskie Państwo Podziemne z członkami białoruskich środowisk politycznych w latach 1941-1944. Po ataku III Rzeszy na ZSRR obszary zamieszkane przez Białorusinów znalazły się pod okupacją niemiecką. Zmieniło to sytuację zarówno działających na tym terenie struktur Polskiego Państwa Podziemnego, jak też białoruskiego ruchu narodowego. Przekonanie o nieuniknionej przegranej III Rzeszy powinno było rodzić świadomość wspólnoty celów. Czy potrafiono jednak wyjść z wcześniejszego impasu wzajemnych animozji, niedowierzań, uprzedzeń, lekceważenia i niedoceniania? By uzyskać odpowiedź na to pytanie, należy sięgnąć do zachowanego materiału źródłowego. Analiza dokumentów archiwalnych pozwala jednoznaczne stwierdzić, że Polskie Państwo Podziemne nie traktowało białoruskiego ruchu narodowego jako poważnego partnera. Jego członkowie stali na stanowisku utrzymania przedwojennych granic, co determinowało charakter prowadzonych rozmów. Nie doceniano też zaplecza białoruskiego ruchu narodowego, które mogło odegrać kluczową rolę $\mathrm{w}$ zmianie sytuacji politycznej w regionie. Mimo to grupka działaczy białoruskich stała na stanowisku porozumieniu z Polakami (Wacław Iwanowski, Jan Stankiewicz, Radosław Ostrowski), poszukiwała kontaktów z Polskim Państwem Podziemnym. Rozmowy miały charakter nieregularnych wymian zdań prowadzonych na niskim szczeblu, raczej sondażowych niż problemowych. Takie podejście skazywało je na porażkę i sprawiło, że ułożenie relacji polsko-białoruskich w warunkach wojennych okazało się wyzwaniem, które przerosło obie strony, a także zaważyło na losach obu narodów po II wojnie światowej.
\end{abstract}

Slowa kluczowe: Polskie Państwo Podziemne, rozmowy polsko-białoruskie, białoruski ruch narodowy, Radosław Ostrowski, Wacław Iwanowski

\title{
Анатацыя
}

Тэмай дадзенага артыкула з' яўляюцца перамовы, якія праводзіліся паміж Польскай падпольнай дзяржавай і членамі беларускіх палітычных суполак у перыяд 1941-1944 гг. Пасля нападзення Трэцяга рэйха на СССР тэрыторыі, на якіх пражывалі беларусы, трапілі пад нямецкую акупацыю. Гэта паўплывала як на дзейнасць Польскай падпольнай дзяржавы, так і на беларускі нацыянальны рух. Перакананне пра непазбежнае паражэнне Трэцяга рэйха павінна было прывесці да ўсведамлення агульнай мэты. Ці змаглі, аднак, зразумець польскі і беларускі бакі, што знаходзіліся ў тупіку ўзаемных варожасці, недаверу, прадузятасці, пагарды, недаацэньвання? Адказ на гэтае пытанне трэба шукаць у архіўных матэрыялах. Аналіз дакументаў дазволіў нам адназначна сцвердзіць, што Польская падпольная дзяржава не ставілася да беларускага нацыянальнага руху як да сапраўднага партнёра. Яе члены лічылі, што неабходна вярнуць даваенныя межы, што абумоўлівала характар усіх перагавораў з беларускім бокам. Неадпаведна быў ацэнены рэзерв беларускага нацыянальнага руху, які мог сыграць асноўную ролю ў змене палітычнага становішча ў рэгіёне. Нягледзячы на гэта група беларускіх дзеячоў была зацікаўлена пагадненнем з палякамі (Вацлаў Іваноўскі, Ян Станкевіч, Радаслаў Астроўскі) і спрабавала наладзіць зносіны з Польскай падпольнай дзяржавай. Гэтыя кантакты аднак не мелі рэгулярнага характару, праводзіліся на нізкім узроўні і з' яўляліся хутчэй зборам інфармацыі, чым праблемнай дыскусіяй. Па прычыне такога падыходу загаддзя было вядома, што перамовы скончацца паразай. Узровень кантактаў сведчыў пра тое, што 
наладзіць польска-беларускія адносіны ў ваенных умовах было выклікам, які перавысіў магчымасці абодвух бакоў, а пасля другой сусветнай вайны паўплываў на лёс абодвух народаў.

Ключавыя словы: Польская падпольная дзяржава, польска-беларускія перамовы, беларускі нацыянальны рух, Радаслаў Астроўскі, Вацлаў Іваноўскі, Ян Станкевіч

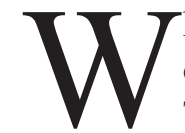

hen World War II started and the Second Polish Republic came under the occupation of its neighbours, its political life underwent sweeping changes. These processes were extremely glaring in what was the north-eastern areas of Poland, inhabited by Belarusian population. They were first to enter the Soviet, Lithuanian, and later German (after the Third Reich's attack on the USSR) area of influence. Both occupiers eradicated the entire political life in those regions, allowing for only a few concessions. In the case of Belarusians, the restrictions introduced revealed the clashing effects of the policy carried out by consecutive regimes.

The Polish Underground State (PUS) tried to adapt its structures to the new conditions. The results varied. Their work was affected by the national, linguistic and religious specificity of the former north-eastern voivodships. It was primarily inhabited by the Belarusian population, a large Polish community, a significant (before their extermination) group of Jews, as well as Lithuanians in some areas. Except for the Jewish community, each group wanted to play a dominant role in the region. The Polish underground had a rather non-pragmatic attitude to this issue, not only in post factum consideration. There were, of course, groups in its ranks which recognised the importance of the issue, but they could not impose their views on their opponents. This inability was perfectly reflected in their attitude to Belarusians. In general, the reports of the Polish Underground State structures contained information on the moods among the pro-Polish part of the Belarusian elite. Rarely, however, did they clearly express that PUS should seek contact and agreement with them. The Belarusian factor was generally considered irrelevant because 'Belarusians had no policy of their own and chose the solution which had the greatest force potential and development opportunities at that moment' (AAN, DRC, 202/III/127). This was to mean that 'the main direction of Belarusian political thought' was to seek support among German factors or to 'build the future based on the Soviets'. In these assessments, it was the weakness and the political orientation of the Belarusian national movement at the time that was regarded as the essence of the problem. However, PUS did not analyse the potential of the Belarusian nation-building process or its importance for the post-war position of Poland. In addition, the reports on the mutual relations between the nations show the fruitless and unreciprocated attempts of the Belarusian side to seek contact with the Polish Underground State (AAN, DRK, 202/III/129, p. 28). 
The new administrative division under the German occupation split up the areas inhabited by Belarusians among several separate units. On the other hand, the authorities made some concessions to the Belarusian population, allowing them to work in local administration offices, security services, and even education. The Polish underground was dissatisfied with this measure, considering it a threat to its influence (Grzybowski, 2010a, p. 54). In their opinion, the most active structures of Belarusian institutions were built in Minsk, Novgorod, Baranovichi and Slonim, while those in Vilnius did not have much importance. PUS consistently focused on the organizational weakness of Belarusian communities, which, however, should not have interfered with the need to develop some objectives and relations with neighbours. It was not a simple task, especially given that the mutual relations were more tense as a result of two occupations. At the same time, as Jerzy Grzybowski notes, 'The background to the conflict had already existed since the interwar period' (Grzybowski, 2011a, p. 82). War conditions intensified the conflict while the fight for power and influence moved to a new dimension. This is evidenced by the efforts of both parties to master all possible levels of power in the local administration system, as well as in direct clashes and the use of terror which took a human toll (Grzybowski, 2011a, pp. 77-105; Prawdzic-Szlaski, 1989, pp. 92-93, 202-203, 231).

The programme of the Polish Government-in-Exile proved crucial for in shaping the position of the Polish Underground State towards the Belarusian population. It stipulated that the pre-war eastern border of the Polish state should be maintained and any proposals suggesting its course be changed were rejected, not allowing for the loss of the smallest scrap of the Polish area. However, it was not this element that sealed the fate of Polish-Belarusian talks, limited them or doomed them to failure. The problem was that the absolute majority of activists in the Polish territory and in the Polish Government-in-Exile, apart from a few politicians, did not see any need for such talks whatsoever. All meetings, if the parties decided to hold them at all, proved symbolic in practice and held for the purpose of reconnaissance. Occasionally, there was an attempt to reach an agreement on a local scale. Moreover, negotiations with Belarusians or even the intentions to hold them were kept secret not only from the general public but also from the majority of underground members.

After the September defeat, a group of Belarusian politicians advocated the idea of seeking agreement with Poles. Its main actors were Jan Stankiewicz and Wacław Iwanowski. The members of the group saw the possibility of establishing contacts with Western countries through their contacts with the Polish Government-in-Exile (Grzybowski, 2010a, p. 64; Turonek, 1983, pp. 138-140). At the same time, they could not afford to be excluded from political life in Belarus under German occupation. Similarly to Jerzy Turonek, Marek Wierzbicki claims that it is 'probably the reason why Stankiewicz and Iwanowski split their roles in the first half of 1940, with Iwanowski acting officially and cooperating with the German authorities, while Stankiewicz was organising an underground political organisation which would not be burdened with the stigma of collaborating with Germany. This was the dawn of the Party of Bela- 
rusian Nationalists (PBN), founded by Stankiewicz in Warsaw in June 1940. It was joined primarily by those members of the Belarus Committee in Warsaw who were in opposition to the policy of Dr Mikołaj Szczors and Fr. Wincenty Godlewski. (Wierzbicki, 2004, p. 96; Turonek, 1983, pp. 137-145; Romanko, 2008, pp. 130-131).

For Jerzy Grzybowski, this issue looks much different:

It is possible that Stankiewicz, a supporter of the Polish-Belarusian federation, made an attempt to establish contacts with the Polish underground on his own, unbeknownst to the other party members. In order to appear more earnest, he used PBN's non-existent authorisation and introduced himself as a representative of the underground organization. Iwanowski's participation in the party in this period is rather doubtful. It was only after the outbreak of the German-Soviet war that the Iwanowski-Stankiewicz group symbolically adopted the name of the PBN during their negotiations with the ZWZ-AK in order to gain more recognition in the eyes of Polish negotiators. Apart from the its name, that symbolic PBN had probably nothing to do with the earlier organization of that name (Grzybowski, 2010a, p. 77).

Among Belarusians, the question of talks with Poles led to emotional discussions and vastly different reactions. The pre-war policy of Polish governments discouraged Belarusians from cooperation (Grzybowski, 2010a, pp. 56-57, 79; Turonek, 1989, pp. 39-41). This was perfectly reflected in the first negotiation attempts initiated during the Soviet occupation. In February 1941 in Vilnius, Fr. Kazimierz Kucharski tried to hold talks with Belarusians on behalf of Colonel Nikodem Sulik, the commander of the Vilnius District of the Union of Armed Struggle at the time (ZWZ, future Home Army). The Belarusian side was represented in them by Stanisław Hrynkiewicz. The talks did not bring the expected results as no arrangements were made (SPP, O/VI, A.293; Grzybowski, 2010a, pp. 76-77; Tomaszewski, 1993, pp. 142-143; Tomaszewski, 1999, pp. 149-150; Piskunowicz, 2005, pp. 52-53). The Third Reich's attack on the USSR finally brought a significant change, especially to the rate of contacts.

When the Third Reich took over the power over the areas occupied by the USSR, the pre-war property relations were restored. In the opinion of Belarusians, it was the sign of Germans' support for Poles. The first months of the German occupation was highly disappointing for them. Contrary to the expectations of Belarusian nationalists, the Germans neither established an independent Belarusian state nor allowed for unrestricted political activity (Wierzbicki, 2004, pp. 97, 105).

In the summer of 1941, the Party of Belarusian Nationalists sought contact with the Information and Propaganda Bureau at the ZWZ General Headquarters. It did not induce any permanent communication, which Belarusians saw as a result of the negative attitude of the Polish side towards the talks. Poles were allegedly consistent in their depreciation of the importance of the Belarusian agency and unwilling to discuss the revision of borders (Wierzbicki, 2004, pp. 97, 105; Turonek, 1983, pp. 138-140). In November 1941, Wacław Iwanowski contacted Lieutenant Samuel Kostrowicki from the 2nd Division of the ZWZ General Headquarters. According to some historians, 
Iwanowski tried to gain the trust of Poles and consciously agreed to employ several active members of the Polish underground in the Minsk administration (Grzybowski, 2010b, p. 231; Turonak, 2006, pp. 141-142).

In 1942, Polish underground reports revealed that the Party of Belarusian Nationalists was seeking contact again. The leaders of the armed structures in the country acknowledged that the need to start talks was urgent at that moment. They put forward the idea to issue a manifesto regarding the Belarusian question, which would depict the mutual relations positively and offer some concessions. The appeal was described the following way:

Political life concentrates in the secret Party of Belarusian Nationalists (PBN), whose central committee is based in Minsk. The Central Committee pursues a dual course of action: outside, it cooperates with Germany, trying to appease the enemy, but in fact seeks agreement with the Allies through Polish structures. PBN does not believe in the victory of Germans and considers Russia to be its main adversary regardless of its system. For PBN, the future of the nation lies in the victory of the Allied Forces. Aware of scarce possibilities, the party wants Belarus to enter into the confederation of Slavic states within its ethnic borders or to form a union with Poland in that we would have a common army and foreign affairs policy. The official demand is that Poland recognise the Curzon line as a border in exchange for equal rights for Poles in Belarus. They do realise this request is impossible to accede to and assure us in confidence that they are willing to make concessions in exchange for assistance in establishing the independent Free Belarus with the capital in Minsk. The Central Committee of the party is secretly trying to make contact with us, unbeknownst to its party members, and pleads our intercession with the Allies, but refuses to cooperate at the very moment and does not want to counteract anti-Polish action in the field for fear of engaging the occupier' $\mathrm{s}$ attention' (SPP, Ministry of Interior - WK, 017, p. 401).

The arguments presented in the document above were reiterated a number of times in reports on the Polish-Belarusian relations sent throughout the following years to London. At the same time, any contact between Belarusians and Germans would be portrayed as being against the interests of Poles. For this reason, any talks with Belarusian activists were merely incidental, as confirmed by report No. 111 of March 2, 1942, signed by general Stefan Rowecki, commander of the Home Army. A document he sent to London, not deciphered until June 2, 1942, states that Polish politicians had been informed that it was only due to the prolonged war that 'some (Belarusian) activists (...) were trying to make contact with Polish groups and reach an agreement established on the ground of common defence against Russia. These people want to liberate the whole Belarus with the help of Poland and cooperate closely in the form a federation, but they press radical territorial demands, setting the future borders of Belarus along the line from Rosław and Bryansk up to and including Biała Podlaska' (SPP, O/VI, A.251, p. 16).

The leaders of the Polish armed structures were much more committed to the idea of taking advantage of the current political situation as soon as possible in the relations 
with Belarusians than the members of the civil structures. The reports sent to London described attempts of Belarussian communities to contact the Polish underground, suggesting that failing to respond promptly could lead to Germans interfering with its future plans. If the situation on the Eastern Front deteriorated, Germany would probably come up with new proposals for Belarusians (SPP, O/VI, A.251, p. 16). According to the Home Army Headquarters, it was also necessary to react for the sake of their own military plans, such as the organisation of an uprising in the areas inhabited by Belarusians. To anticipate potential complications, General Stefan Rowecki stated that:

These difficulties could be overcome by appeasing the area in a timely manner by means of propaganda efforts and conciliating the Belarusian population as a result. (...) This could be achieved by:

a) issuing an appeal from the Polish Government to citizens of Belarusian nationality depicting the coexistence of both nations after the war in a manner more suited to key state interests than was the case in 1939. It would be desirable to particularly emphasize the cultural and economic aspect (agricultural reform) in the manifesto;

b) contacting those Belarusian activists who are seeking support in Poland;

c) promptly launching propaganda tools for combatting anti-Polish arguments in the field.

d) appointing Belarusian representatives to the National Council.

e) filing a request to the Vatican on behalf of the Polish Government that a Latin bishop be appointed in the areas of Belarusian ethnicity in the eastern territories of the Republic of Poland, honouring the wishes of the Belarusian population. In accordance with the concordat, the candidate would have to obtain the consent of the Polish Government (SPP, O/VI, A.251, p. 17).

The Polish Government-in-Exile was limited in its attempts to coordinate the ongoing Polish-Belarusian relations by the scarce amount of information it received. Nevertheless, Antoni Serafiński of the Ministry of the Interior argued in his Notes to the report on the Belarus of March 2, 1942 (issued in June that year) that the information he had 'allowed him to grasp the situation'. He assessed the sentiments in the region:

The people acting as Belarusian leaders at the moment put us in a very favourable position as they are familiar to us. It is not impossible to establish contact and a common language with them, especially in view of their attempts to contact the Polish side as indicated in the report.

Later in the document, the author states outright that all cases of Belarusian politicians seeking contact with the Polish side 'should definitely be used'. Serafiński and a group of like-minded people believed an appropriate declaration was indispensable for holding talks and, more importantly, creating a Belarusian decision-making centre. Such a document, as in the case of Ukrainians, had still not been published. This strongly discouraged Belarusian politicians from cooperation and at the same time hampered Polish initiatives aimed at gaining allies. 
According to reports of the Polish underground, Radosław Ostrowski, a former member of the Belarusian Peasant-Workers' Hromada, was one of the main candidates for negotiations. Wacław Iwanowski was also considered due to his family relationships. However, neither of them participated in the Minsk meetings of July 1942 with Zofia Dobrzyńska, delegate of the Information and Propaganda Bureau (BIP) of the Home Army Headquarters. The Belarusian side was represented by Jan Stankiewicz, acting as a member of the PBN (Siamaszka, 1994, p. 173; Wierzbicki, 2004, p. 107). PBN was the primary environment for finding potential partners. Dobrzyńska was an important, but not the only person who engaged in talks with Belarusians on behalf of the Polish underground. Other BIP employees were also entrusted with similar activities in Minsk. The head of the Department for Nationality Issues, Władysław Tomkiewicz, performed them from August 1941 to spring 1943, when he became the chairman of the National Council and the director of the Nationality Bureau of the Government Delegation for Poland. Since the spring of 1943, Stanisław Herbst was responsible for negotiations with Belarusians (Mazur, 1987, pp. 82-84, 89).

The talks confirmed that the Home Army Headquarters was more involved in the case than civilian structures. The negotiation options were unfortunately limited due to the absence of clear guidelines from the Polish Government-in-Exile (Turonek, 1983, pp. 140-141). On the other hand, the scale of Polish involvement indicated that the talks had at most a secondary priority. In the message to General Stefan Rowecki of August 3, 1942, it was reported that guidelines on the Belarusian issue were yet to be sent (SPP, O/VI, 022, p. 21). This means that the postulates prepared in June were still subject to internal discussion. This is confirmed by the documents of the National and Religious Department of the Political Department of the Ministry of the Interior. On September 17, 1942, a member of the Department supported the proposal to 'use all the signs of Belarusian activists (...) acting as leaders seeking contact with the Polish side'. He also argued that 'reaching an agreement is not impossible', all the more so because the Belarussian Council in Minsk consisted of people who had cooperated with the Polish authorities before the war (SPP, O/VI, 251, p. 19).

The following months did not see any clear progress in the Polish-Belarusian negotiations. On December 19, 1942, Władysław Tomkiewicz talked to Jan Stankiewicz (AAN, DRC, ref. 202/III/198, pp. 97-101). As Grzegorz Mazur notes, 'Unfortunately, we know nothing about these negotiations' (Mazur, 1987, p. 89).

The Polish Underground State and the London Government were strongly divided on their position on this issue. For the most part, they were far from making any proposals or concessions. The decisions the Polish Government-in-Exile made regarding Belarus were neither clear nor resolute. The documents preserved show a generally friendly and positive approach to the problem, but it did not look promising in practice. When it was necessary to take action, they disengaged, commenting that 'any steps towards an autonomous organization of the north-eastern territories could be advanced (...) only in case of absolute necessity'. This alarmed the politicians who saw the urgent need for official declarations on the matters of Belarus. Such apprehensive 
position was visible among the part of the national leadership of the armed underground who informed their London superiors. A formal declaration regarding Belarusian as Polish citizens was finally issued in the form of a special appeal to the country at the beginning of 1942. The document, however, never reached its addressees in the country (and was not sent for several subsequent months), yet managed to spark many deep domestic disputes (IPMS, MSW, A.9E/113).

According to Jerzy Turonek, talks continued in Warsaw in January 1943 during the conference of representatives of both sides. Again, they did not result in a breakthrough. The Polish side consistently stressed that there was no possibility of modifying the pre-war border to any extent (Wierzbicki, 2004, p. 107; Sakałouski, Lachouski, 2000 , p. 16). The national reports sent to London at that time painted a rather unfavourable picture of Belarusians. The mass population was supposedly anti-German, but the elites were accused of cooperating with the occupier, allegedly to 'present the world with a fait accompli' (IPMS, Ministry of Interior, ref. A.9E/113). In his report of March 20, 1943, General Rowecki informed the the $6^{\text {th }}$ Branch of General Staff of the Commander-in-Chief:

Political life is concentrated in the secret Belarusian Nationalist Party. On the outside, it cooperates with Germany, while quietly it seeks agreement with us and the Czechs, their goal being an independent Belarus as a part of the Central European confederation. The BPN's attitude towards Russia is clearly hostile. They would like to draw up their eastern border on Staraya Russa and Vyazma, and the western border on the Curzon line. (...)

The President of PBN has contacted us personally. He does not agree on taking clearly anti-German action as he would rather save Belarusian forces for the fight with Russia. He demands that the Polish Government officially recognise an autonomous Belarusian state within the Polish borders. In practice, this would amount to a self-government on a wide scale, but in fact they merely need an effective slogan for the BPN to launch an action among the masses (IPMS, PRM, 106, p. 19).

The Home Army leaders grew impatient as the decision regarding the appointment of a Belarussian representative to the National Council never came. Neither did an official document that would finally allow for formal negotiations. Therefore, on May 4, 1943, it filed another enquiry to Government of the Republic of Poland in London. In response, the Ministry of Information and Documentation explained:

On the basis of national reports on the Belarus issue of March 2, 1942, an appeal from the Government of the Republic of Poland to the Belarusian population was prepared and was forwarded to the Social Department on February 8, 1943 with the purpose of being sent. Whether and when the document was sent and whether its receipt was confirmed, that I could not determine because the Social Department has not responded to the multiple queries I raised. In the said appeal, the Government established its political position on the Belarus issue and ensured its implementation. Therefore, if the appeal was sent and reached the na- 
tional structures, its content is sufficient for negotiations with representatives of Belarusians, as well as for the appropriate propaganda. However, if it was not sent or did not reach the country, it should be immediately encrypted. (IPMS, Ministry of the Interior, file A.9E/113).

The intensity of Belarusians attempts to contact the Polish side, regardless of their intentions, depended on several factors. On the one hand, the defeat of the Germans on the Eastern Front forced them to reach a prompt agreement with the Polish Underground State (Wierzbicki, 2004, p. 107). On the other hand, the Polish underground tried to penetrate Belarusian institutions (Grzybowski, 2011b, pp. 106, 108), whereas the armed formations which were expanding their structures in the Novgorod and Vilnius regions invited Belarusians into their ranks, freeing them from the influence of the Belarusian movement (Siamaszka, 1994, p. 131). Moreover, some Belarusian activists moved west after the changes at the front in the second half of 1943. Upon reaching Warsaw, they lost contact with field operations.

In the second half of 1943, the stance of the Polish underground towards Belarus was presented by the newly formed Nationalities Council. This institution operated within the Government Delegation for Poland. In an appeal of October 12, 1943, it warned that the position of eastern voivodships within the Polish state was threatened not only by the new Soviet occupation but also by 'extreme minority elements', which is why 'the raison d'état requires that substantial Polish forces be demonstrated in the area' (AAN, DRC, 202/XVI/3). A month later, on November 15, 1943, it adopted a resolution indicating that the USSR would strive to preserve the eastern territories, thus it constituted 'a common danger for Poles, Ukrainians, Belarusians and Lithuanians'. It called for 'swift Polish-Ukrainian and Polish-Lithuanian negotiations'. The part of that document which was to specify these issues, however, did not mention the talks with Belarusians in any way (AAN, DRC, 202/XVI/3).

A month earlier, in October 1943, Zofia Dobrzyńska visited Minsk again. As a BIP delegate of the Home Army, she began talks with a representation of several Belarusian environments, together with one of the district commanders of the Home Army. Upon receiving the information about the talks, the local civil structures of the Polish Underground State complained that the negotiations were held unbeknownst to the regional delegate of the government, and the Home Army envoy proclaimed herself as the official representative of the 'Polish government'. During the talks, the Polish emissaries offered to cooperate on a political level and to introduce two delegates to the National Council in London. The Belarusian side responded positively and issued two memorials: one in case the pre-war border was preserved, the other if it was to extend to the east (AAN, DRK, 202/II/49, pp. 312-313).

At the end of 1943, the underground reports sent to London constantly argued that some Belarusian politicians were desperately seeking contact with Poles (AAN, DRC, A9/V/20). Radosław Ostrowski, who was temporarily working in the German military administration in the Smolensk region, was again nominated as the potential partner for negotiations. Incidentally, he had tried to reach the Home Army Headquarters in 
October 1942, but did not manage to do it until several months later as the head of the Belarussian Central Council (established in December 1943). Marek Wierzbicki believes that the Polish side wanted to use these talks to compel the armed formations of the Belarusian National Defense to serve their own purposes (Wierzbicki, 2004, p. 108).

The local structures of the Government Delegation for the Country were not pleased with the fact that the Home Army Headquarters 'appropriated' the negotiations with Belarusians (AAN, DRC, 202/III/130, p. 95). The Eastern Bureau in the Department of Internal Affairs of the Government Delegation of the Republic of Poland complained that it had been generally misinformed about the state of Belarusian affairs and the ongoing talks with Belarusians (AAN, DRC, 202/II/49, p. 204).

Meanwhile, the number of leading Belarusian politicians was diminishing. The centres of Belarusian political life suffered a series of attacks. Many supporters of negotiations with Poles fell victim to the onslaught. Among them was prof. Wackaw Iwanowski, killed on December 7, 1943 in Minsk (AAN, DRC, 202/XVI/2).

Regardless of the field events and the position of the National Council, attempts at mutual scrutiny continued. They were described by the author of the Eastern Section report of December 1943 for the Information and Press Department. Indicating the lasting standstill, he wrote:

The Polish-Belarusian negotiations I presented in the previous post have not moved forward. Instead of a memorandum, the Belarusians developed an appeal to the population of the Kresy. The Poles were dissatisfied with its content and rejected it, so they were entrusted with preparing it. Now they seem to be unable to find the right words. The talks are stalling (AAN, DRK, 202/III/130, p. 95).

The situation did not change in the course of 1944. In January, reports from the Nowogródek District of the Home Army indicated that Belarusians 'are trying to communicate with the Poles' (AAN, DRC, 202/XVI/2). The Polish side claimed that Belarusians still insist on their delusive plans and would use their contacts with Poland only to fight the Russians (USSR). It was stressed that they had radical demands regarding the borders and the Polish-Belarusian federation. However, faced with the alternative of the Soviet occupation returning, Belarusian activists quickly agreed to further concessions. Such position was adopted by representatives of the Vilnius National Committee (Union of Belarusian Democrats, Party of Belarusian Nationalists, Christian Democracy). Activists in Minsk were more approving of the agreement than in Vilnius (AAN, DRC, 202/III/127, pp. 5-6). At that time, the Nationalities Bureau received a Belarusian memorandum addressed to the authorities of the Polish underground. The employees of the Bureau still believed that the Polish-Belarusian relations was easy to manage (AAN, DRC, 202/II/49, p. 229).

During that period, all talks were 'initiated by Warsaw' and were met with hesitation of Belarusian activists. Conducted with a representative of the Belarusian Na- 
tional Committee in Vilnius, the talks did not give rise to any specific arrangements 'beyond general statements and oral exchange of views'. The accounts showed that Belarusian activists were required to take 'a deputy's oath' and offered to participate in a joint Polish-Belarusian guerrilla under Polish leadership. There Belarusian elites were allegedly bitter about the lack of an appeal to Belarusians from the Polish structures, neither the underground authorities nor the Government of the Republic of Poland in London. It aroused 'the suspicion that Poles did not recognise the Belarusian issue, and that they wanted to deceive the Belarusian people just like they had deceived them by signing the Peace of Riga with the Soviets' (AAN, DRC, 202/III/127).

In February 1944, the German authorities agreed on the mobilisation of The Belarusian Home Defence. This turn of events did not appeal to the Polish underground. However, in April 1944, Belarusian activists tried to contact the headquarters of the Vilnius Home Army District again. The talks were of 'informative nature' (AAN, DRC, 202/III/129, p. 72). On March 10, 1944, Colonel Stanisław Gano, head of the Department of the $2^{\text {nd }}$ Branch of General Staff of the Commander-in-Chief, was informed that the Belarusian Central Council (BCR) announced its mobilisation with the consent of the Germans and was preparing to create an armed force led by its chairman Radosław Ostrowski. Consequently, the leaders of Polish armed structures were even more interested in his persona (SPP, O/VI, A.153, p. 285; Army, 1990, pp. 448449). He was now characterized as extremely talented in respect of organisation, who, not being a supporter of the occupation authorities, 'wants (...) to create a number of accomplished facts in Belarus' with their help, so that those who come after them will have to acknowledge. According to the report of August 25, 1944, Ostrowski 'currently does not show any kind of hostility towards Poles or Poland in his actions or even official speeches. On the contrary, he seeks to establish contact. He has let us know recently that Belarus stands and will stand by Poland despite all appearances. Given his growing popularity, it is necessary for us to reach an agreement with him'. (SPP, MSW-WK, 014, p. 119).

Jerzy Sobolewski also tried to talk to the Polish underground on behalf of the BCR. However, there is not much information about his meetings with members of the Polish underground in Druya, aimed at securing short-term military cooperation (IPMS, PSP, Kol.30/VI/10). These surely were not the only interactions between the Polish underground and Belarusian activists that are almost forgotten today. The last of them might have been the declaration of the Belarussian National Democratic Union of June 20, 1944. It was addressed to the Government Delegate for the Country and pleaded Poles to inter alia leave Belarusian territories within the Polish borders (AAN, 202/II/71, p. 131; Piskunowicz, 2005, pp. 62-63) This, as we may sadly conclude today, can be the reason why we are still not able to fully reproduce them.

When the Soviet army entered Belarus later occupied Poland as well, the Polish-Belarusian talks were no longer purposeful. Yet they still can be considered an interesting event in the history of World War II and mutual relations. Despite scarce source material, there is no doubt that the negotiations were conducted on a small scale, rather 
disregarded, and burdened with expectations concerning short-term and local goals. This approach had a significant impact on the perception of the Polish Underground State by Belarusian communities. It was only during the years of German occupation that the Polish authorities realized how serious the threat of losing the pre-war eastern voivodships was. Unfortunately, at that time it was essentially impossible to maintain them without an agreement with Belarusians.

Translated into English by Marek Robak-Sobolewski

\section{List of sources}

AAN - Polish Central Archives of Modern Records in Warsaw sun.

DRK - Delegatura Rządu na Kraj, reference codes - 202/II/49, 202/II/71, 202/III/127, 202/

III/129, 202/III/130, 202/III/198, 202/XVI/2, 202/XVI/3.

IPMS - Polish Institute and Sikorski Museum in London.

PSP - Papiery Stanisława Paprockiego, reference code - Kol.30/VI/10.

PRM - Prezydium Rady Ministrów, reference code - 106.

MSW - Ministerstwo Spraw Wewnętrznych, reference code - A.9E/113, A9/V/20.

SPP - Polish Underground Movement Study Trust.

MSW-WK - Ministerstwo Spraw Wewnętrznych - Wydział Krajowy, reference code - 014, 017.

O/VI - Oddział VI Sztabu Naczelnego Wodza, reference code - A.022, A.153, A.251, A.293.

Armia Krajowa w dokumentach 1939-1945. Vol. 3: Kwiecień 1943-lipiec 1944. Tadeusz Pelczyński (ed.). (1990). Wrocław: Zakład Narodowy im. Ossolińskich.

Prawdzic-Szlaski, Janusz. (1989). Nowogródczyzna w walce 1940-1945. Londyn: Oficyna Poetów i Malarzy.

\section{References}

Grzybowski, Jerzy. (2010a). Białoruski ruch narodowy a III Rzesza (wrzesień 1939-czerwiec 1941). Przegląd Historyczny, 1, pp. 53-88.

Grzybowski, Jerzy. (2010b). Polsko-białoruskie próby porozumienia w latach II wojny światowej (w kraju i na emigracji). Echa Przeszłości, 11, pp. 227-247.

Grzybowski, Jerzy. (2011a). Białoruski ruch niepodległościowy wobec Polski i Polaków na ziemiach północno-wschodnich II Rzeczypospolitej pod okupacją niemiecką (1941-1944). Dzieje Najnowsze, 1, pp. 77-105.

Grzybowski, Jerzy. (2011b). Pogoń między Orłem Białym, Swastyka i Czerwona Gwiazda. Biatoruski ruch niepodległościowy w latach 1939-1956. Warszawa 2011. 
Mazur, Grzegorz. (1987). Biuro Informacji i Propagandy SZP-ZWZ-AK 1939-1945. Warszawa: Instytut Wydawniczy PAX.

Piskunowicz, Henryk. (2005). Polskie podziemie a kwestia białoruska w latach 1941-1944. In: Jan Jerzy Milewski, Anna Pyżewska (eds.). Stosunki polsko-białoruskie w województwie białostockim w latach 1939-1956. Warszawa: IPN.

Roman'ko, Oleg. (2008). Legion pod znakom Pogoni. Belorusskie kollaboracionistskie formirovaniâ v silovyh strukturah nacistskoj Germanii (1941-1945). Simferopol': Antikva. [Poманько, Олег. (2008). Легион под знаком Погони. Белорусские коллаборационистские формирования в силовых структурах нацистской Германии (1941-1945). Симферополь: Антиква].

Sakaloǔskì, Uladzìmer, Lâhoǔskì, Uladzìmer. (2000). Nâmeččynaj belaruskì nacyânal'ny ruh na pârèdadnì j u peršyâ gady Drugoe Sus'etnae Vajny. Białoruskie Zeszyty Historyczne, 13, pp. 5-20. [Сакалоўскі, Уладзімер, Ляхоўскі, Уладзімер. (2000). Нямеччынай беларускі нацыянальны рух на пярэдадні й у першыя гады Другое Сусьетнае Вайны. Białoruskie Zeszyty Historyczne, 13, pp. 5-20.]

Sâmaška, Âŭgen. (1994). Armîa Kraëva na Belarusì. Mìnsk: Belaruskae vydaveckae Tavarystva „Наta”. [Сямашка, Яўген. (1994). Армія Краёва на Беларусі. Мінск: Беларускае выдавецкае Таварыства „Хата”].

Tomaszewski, Longin. (1990). Kronika wileńska 1939-1941. Warszawa: „Pomost”.

Tomaszewski, Longin. (1999). Wileńszczyzna lat wojny i okupacji 1939-1945. Warszawa: Oficyna Wydawnicza Rytm.

Turonak, Ûry. (2006). Vaclaǔ İvanoǔskì ì adradžènne Belarusì. Mìnsk: Medysont. [Туронак, Юры. (2006). Ваилаў Іваноўскі і адраджсэнне Беларусі. Мінск: Медысонт].

Turonek, Jerzy. (1983). Kwestia białoruska w polityce obozu londyńskiego (1941-1944). Studia z Dziejów ZSRR i Europy Środkowej, 19, pp. 137-145.

Turonek, Jerzy. (1989). Białoruś pod okupacją niemiecka. Warszawa-Wrocław: WERS.

Wierzbicki, Marek. (2004). Białorusini polscy w okresie przełomu (1939-1945). Pamięć i Sprawiedliwość, 2, pp. 83-113. 